\title{
GMR
}

\section{Diallel crosses for resistance to Macrophomina phaseolina and Thanatephorus cucumeris on cowpea}

L.R.L. Lima ${ }^{1}$, K.J. Damasceno-Silva ${ }^{2}$, M.A. Noronha ${ }^{3}$, D.A. Schurt ${ }^{4}$ and M.M. Rocha ${ }^{2}$

${ }^{1}$ Programa de Pós-Graduação em Genética e Melhoramento, Universidade Federal do Piauí, Teresina, PI, Brasil

${ }^{2}$ Embrapa Meio-Norte, Teresina, PI, Brasil

${ }^{3}$ Embrapa Tabuleiros Costeiros, Rio Largo, AL, Brasil

${ }^{4}$ Embrapa Roraima, Boa Vista, RR, Brasil

Corresponding author: K.J. Damasceno-Silva

E-mail: kaesel.damasceno@embrapa.br

Genet. Mol. Res. 16 (3): gmr16039804

Received August 15, 2017

Accepted August 30, 2017

Published September 27, 2017

DOI http://dx.doi.org/10.4238/gmr16039804

Copyright (C) 2017 The Authors. This is an open-access article distributed under the terms of the Creative Commons Attribution ShareAlike (CC BY-SA) 4.0 License.

\begin{abstract}
This study aimed at identifying and selecting through partial diallel analysis, segregating populations of cowpea resistant to Macrophomina phaseolina and Thanatephorus cucumeris, based on the evaluation of general (GCA) and specific combining ability (SCA), involved in the genetic control of resistance. For this reason, 19 grouped cowpea genotypes, considering the resistance to these pathogens, were crossed in partial diallel scheme $14 \times 5$, during 2013 and 2014. The $70 \mathrm{~F}_{2}$ populations and the 19 parents were evaluated in a greenhouse as the reaction to pathogens, separately. The diallel analysis was performed according to the model of partial diallel proposed by Geraldi and Miranda Filho (1988). The additive effects predominated in the genetic control of the traits severity of charcoal rot (SEV) and area under the disease progress curve (AUDPC) to
\end{abstract}

Genetics and Molecular Research 16 (3): gmr16039804 
web blight, enabling the achievement of genetic gain with selection of resistant strains. Analyzing the effects of GCA, the parents BR 14-Mulato, BRS Tumucumaque and BRS Guariba, have a higher concentration of favorable alleles, highlighting, according to the values of SCA, the combinations BR 14-Mulato x MNC02-675F-4-10, BRS Tumucumaque x IT98K-1092-1, BRS Tumucumaque x MNC02675F-4-10, BRS Tumucumaque x MNC02-675F-9-2, BRS Guariba x IT98K-1092-1, BRS Guariba x MNC02-675F-4-9, and BRS Guariba x MNC02-675F-4-10, as the most promising and indicated to obtain lines resistant to M. phaseolina and T. cucumeris in cowpea, simultaneously.

Key words: Vigna unguiculata; Partial diallel; Charcoal rot; Web bligh

\section{INTRODUCTION}

Cowpea [Vigna unguiculata (L.) Walp.] is quite cultivated in many countries of tropical and subtropical regions of Africa, Asia, America, Europe, and Oceania. Due to its high nutritional value, especially since this is a legume rich in protein, carbohydrates, vitamins, minerals, fiber, and low in fat, the cowpea is one of the major components of diet of several low-income populations in the world (Timko and Singh, 2008; Freire Filho et al., 2011).

Because it is a culture of high strategic potential and boasts a large genetic variability and phenotypic plasticity, undemanding in terms of fertility of soils and tolerant to high temperatures, the cowpea has been cultivated in different production systems (Freire Filho et al., 2007). The occurrence of diseases, especially those caused by fungi, constitutes one of the main causes of reduced productivity of cowpea, negatively affecting the quantity and quality of production. Two diseases stand out among the main diseases: charcoal rot, whose etiological agent is the fungus Macrophomina phaseolina (Tassi) Goid, and the web blight, caused by the fungus Thanatephorus cucumeris (Frank) Donk. (anamorphic phase Rhizoctonia solani Kühn).

The presence of high genetic variability, survivability through structures of resistance and wide host range, as well as the lack of registration of inputs which allow the control of charcoal rot and web blight, make difficult their management. In this way, the use of resistant cultivars is presented as one of the most efficient strategies in controlling these diseases (Athayde Sobrinho et al., 2005).

Among the main demands of short term of the Breeding Program of Cowpea related to expansion of the consumer market and to incorporation of producers with a new profile, the development of cultivars resistant to biotic stress still constitutes a challenge for plant breeders (Freire Filho et al., 2013).

It is important to emphasize that in a breeding program aiming at obtaining genotypes with genetic resistance to pathogens, it is necessary to perform genetic studies to define what breeding methods should be adopted. Among the methods of biometric genetic analysis, the diallel is highlighted for allowing the retrieval of information based on the behavior "per se" of a group of parents and their combining ability (Cruz et al., 2012). This information aids in the choice of the segregating populations, with high potential to provide superior progenies and indicate the most appropriate selecting strategy, thus ensuring the efficiency of the program.

However, it is not aware of studies that aimed at genetic improvement for resistance to M. phaseolina and T. cucumeris which have used the technique of diallel crosses as a

Genetics and Molecular Research 16 (3): gmr16039804 
strategy for the identification of potential parents aiming to produce progeny resistant to these pathogens in cowpea.

The present study was carried out with the objective of identifying and selecting segregating populations of cowpea genotypes resistant to M. phaseolina and T. cucumeris, through diallel analysis, based on the evaluation of general and specific combining ability involved in genetic control of resistance to these pathogens, between parents and $\mathrm{F}_{2}$ populations of cowpea.

\section{MATERIAL AND METHODS}

\section{Genetic material}

From results obtained in studies conducted by Noronha et al. (2009), Lima et al. (2012a,b) and Nechet and Halfeld-Vieira (2007), nineteen cowpea genotypes were selected as parents, being divided into two groups. Group A was composed of fourteen genitors of cowpea chosen by presenting resistance to the fungus T. cucumeris, and group B contained five parents who showed reactions of resistance and moderate resistance to the fungus $M$. phaseolina (Table 1).

Table 1. Relationship between cowpea parents with their respective groups of resistance, origin, plant size, and type of grain used in the diallel crosses.

\begin{tabular}{l|l|l|l|l}
\hline Genotype & Group & Origin & Size & Type of grain (subclass) \\
\hline BR14 Mulato & A & Brazil & Semi-prostrate & Brown \\
\hline Canapuzinho & A & Brazil & Semi-erect & Crowder \\
\hline IT98K-491-4 & A & Nigeria & Semi-erect & Rough white \\
\hline IT98K-506-1 & A & Nigeria & Semi-prostrate & Smooth white \\
\hline MNC01-649F-2-1 & A & Brazil & Semi-prostrate & Brown-striped \\
\hline MNC02-677F-5 & A & Brazil & Semi-prostrate & Evergreen \\
\hline MNC02-689F-2-8 & A & Brazil & Semi-prostrate & Green \\
\hline BRS Aracê & A & Brazil & Semi-prostrate & Evergreen \\
\hline BRS Marataoa & A & Brazil & Semi-erect & Smooth white \\
\hline MNC03-737F-5-9 & A & Brazil & Semi-erect & Smooth white \\
\hline BRS Tumucumaque & A & Brazil & Semi-erect & Smooth white \\
\hline BRS Cauamé & A & Brazil & Semi-erect & Black-eyed pea \\
\hline BRS Itaim & A & Brazil & Erect & Smooth white \\
\hline BRS Guariba & A & Brazil & Semi-erect & Black \\
\hline IT98K-1092-1 & B & Nigeria & Semi-prostrate & Evergreen \\
\hline MNC03-761F-1 & B & Brazil & Semi-erect & Brown \\
\hline MNC02-675F-4-9 & B & Brazil & Semi-erect & Brown \\
\hline MNC02-675F-4-10 & B & Brazil & Semi-erect & Brown \\
\hline MNC02-675F-9-2 & B & Brazil & & \\
\hline
\end{tabular}

Seventy crosses were made between the parents of groups A and B, in partial diallel scheme, during 2013 and 2014 in conditions of greenhouse using the method of crossing described by Freire Filho et al. (2005) and Rêgo et al. (2006). After obtaining the $\mathrm{F}_{1}$ generation, the seeds of hybrids were sown in conditions of greenhouse, for the obtaining of $\mathrm{F}_{2}$ generation of each cross.

\section{Evaluation of $\mathrm{F}_{2}$ populations of cowpea genotypes for resistance to Macrophomina phaseolina}

Strain of M. phaseolina (MP 09) used in this study was obtained from the collection of fungi in the laboratory of Phytopathology of Embrapa Meio-Norte. The preparation of the inoculum was performed in accordance with Songa et al. (1997), using as substrate grains

Genetics and Molecular Research 16 (3): gmr16039804 
of rice in the husk, autoclaved at $120^{\circ} \mathrm{C}$ for $20 \mathrm{~min}$, adding five disks of half culture potatodextrose-agar (PDA) with $5.0 \mathrm{~mm}$ diameter, containing mycelia of M. phaseolina, being incubated in B.O.D. during 15 days under temperature of $25^{\circ} \pm 2^{\circ} \mathrm{C}$ and photoperiod of $12 \mathrm{~h}$.

The seeds of $70 \mathrm{~F}_{2}$ populations of cowpea were disinfected in a solution of $\mathrm{NaClO}$ $1.5 \%$ during 2 minutes, rinsed in tap water and placed to dry on paper towel. The sowing was in plastic pots containing substrate ( $70 \%$ soil, $15 \%$ rice straw burnt and $15 \%$ cattle manure) previously autoclaved at $120^{\circ} \mathrm{C}$ for $1 \mathrm{~h}$, and infested in each of the five discs with three rice grains colonized with the pathogen. The witnesses consisted in the deposition of three grains of rice autoclaved in each pit. The experimental design was completely randomized with five replications, and the experimental plot consisted of a pot with five plants.

The evaluation was performed 20 days after sowing, and the severity of the disease estimated with the aid of a scale from zero to five, adapted from Abawi and Pastor-Corrales (1990), in which: $0=$ absence of symptoms; $1=$ lesions limited to the cotyledonary tissues; $2=$ root injuries, and/or reaching the tissues of the hypocotyl in approximately $2.0 \mathrm{~cm} ; 3=$ injuries above $2.0 \mathrm{~cm}$ in length in the region of the neck of the plant; $4=$ stem with its diameter colonized by the fungus and/or with the presence of pycnidia; $5=$ non-germinated seeds and seedlings damping-off.

\section{Evaluation of $\mathrm{F}_{2}$ populations of cowpea genotypes for resistance to Thanatephorus cucumeris}

The isolate 141 T. cucumeris, belonging to the group of anamastose AGI-1A, kept in the collection of fungi in the laboratory of Phytopathology of Embrapa Roraima, was grown on Petri dishes containing culture of PDA and incubated for three days at $25^{\circ} \mathrm{C}$ in the dark. After this period, three disks of mycelium obtained from the periphery of the colony were transferred to Erlenmeyer of $250 \mathrm{~mL}$ containing $100 \mathrm{~mL}$ liquid potato-dextrose (PD), subsequently placed in an incubator (Shaker) at a speed of $250 \mathrm{rpm}$ at $28^{\circ} \pm 2^{\circ} \mathrm{C}$ for 10 days. After this period, the mycelium obtained was filtered, suspended in sterile distilled water and crushed for 1 min using a mechanical shaker. The inoculum concentration was estimated in Neubauer chamber and set to $1 \times 10^{6}$ fragments of mycelium $/ \mathrm{mL}$.

The sowing of $\mathrm{F}_{2}$ populations of cowpea was performed in plastic pots containing soil previously disinfected with fumigant of soil of active principle metam-sodium. Then, four seeds per pot were sown. After the beginning of the germination of seeds, it was done the "thin out" to keep only two plants per pot. The trial was conducted in a completely randomized block design, with four replications, being each repetition composed of a pot with two plants.

The inoculation method used was adapted from Nechet et al. (2009), with the suspension of inoculum mixed with Tween $20(0.05 \%)$ and sprayed in cowpea genotypes thirty days after sowing with the aid of a mini pressurizer. After inoculation, plants were placed in a humid chamber for $6 \mathrm{~h}$ at $25^{\circ} \mathrm{C}$, and then exposed to greenhouse conditions $\left(25^{\circ}\right.$ $\pm 2^{\circ} \mathrm{C}$ ). As witnesses, eight plants of cowpea type black-eyed peas Vaina Blanca were used, where four were sprayed with sterile distilled water with the addition of Tween $20(0.05 \%)$.

The evaluations were performed during five consecutive days from the onset of symptoms, by estimating the percentage of diseased leaf with the aid of the diagrammatic scale proposed by Van Schoonhoven and Pastor-Corrales (1987), ranging from 0-100\%, in that: $0 \%=$ absence of symptoms and $100 \%=$ fully infested plant.

Genetics and Molecular Research 16 (3): gmr16039804 


\section{Statistical analyses}

\section{Analysis of severity of charcoal rot}

With evaluation data of charcoal rot in cowpea genotypes it was calculated the severity of the disease (SEV) in accordance with the index of McKinney (1923), the term:

$$
S E V=\frac{\sum(A \times B)}{(C \times D)} \times 100
$$

where: A: score in the scale; B: frequency; C: total number of plants; D: maximum class in the scale.

\section{Analysis of the reaction of Thanatephorus cucumeris}

From data obtained in the evaluation of the intensity of the web blight in cowpea genotypes it was calculated the area under disease progress curve of web blight (AUDPC) (Campbell and Madden, 1990), based on the formula:

$$
A A C P D=\sum \frac{\left(Y_{i}+Y_{i+1}\right)}{2} \times\left(t_{i+1}+t_{i}\right)
$$

The averages were grouped by Scott-Knott test at 5\% probability, and all analyses were performed with the use of the software Sisvar (Ferreira, 2011).

\section{Diallel analysis}

The average of the parents and the $\mathrm{F}_{2}$ plants obtained through the analysis of SEV and AUDPC were submitted to the diallel analysis according to the model of partial diallel proposed by Geraldi and Miranda Filho (1988) adapted from the Model 2 proposed by Griffing (1956). The effects of the treatments were considered as fixed and the mean squares for the general (GCA) and specific (SCA) of combination were obtained in accordance with the statistical model:

$$
Y_{i j}=\mu+\frac{1}{2}\left(d_{1}+d_{2}\right)+g_{i}+g_{j}^{\prime}+s_{i j}+\bar{\varepsilon}_{i j}
$$

in which: $Y_{i j}$, is the average value of the hybrid combination involving the $\mathrm{i}$-th parent of Group 1 and the $\mathrm{j}$-th parent of group 2; $Y_{0 i}$ is the average of the $\mathrm{i}$-th parent of group $1 ; Y_{0 j}$ is the mean of the $j$-th parent of group $2 ; \mu$, general average of diallel; $d_{1}, d_{2}$, contrasts involving means of groups 1 and 2 and the overall average; $g_{i}$, effect of general combining ability of the $i$-th parent of group $1 ; g^{\prime}$, effects of general combining ability of the $\mathrm{j}$-th parent of group $2 ; s_{i j}$, effect of specific combining ability; $\bar{\varepsilon}_{i j}$, mean experimental error. Statistical analyses were performed using the computational resources of the software Genes (Cruz, 2006).

Genetics and Molecular Research 16 (3): gmr16039804 


\section{RESULTS}

The significance presented by the mean squares of SEV and AUDPC, and between the contrasts of the progenies and the parents by $\mathrm{F}$ test $(\mathrm{P} \leq 0.01)$ (Table 2), indicate the existence of genetic variability among the eighty-nine cowpea genotypes evaluated in the expression of reaction to pathogens, and the possibility of selection of genotypes for resistance improvement.

Table 2. Analysis of variance for the severity of charcoal rot (SEV) and area under the disease progress curve for web blight (AUDPC), analyzed in diallel crosses involving nineteen genitors of cowpea.

\begin{tabular}{l|c|c|c|c}
\hline \multirow{2}{*}{ SV } & \multicolumn{2}{|c|}{ SEV } & \multicolumn{2}{c}{ AUDC } \\
\cline { 2 - 5 } & d.f. & MS & d.f. & SM \\
\hline Genotypes - & 88 & $14.11^{* *}$ & 1 & $13.34^{* *}$ \\
\hline - Progenies $v$ Genitors ${ }^{1}$ & 1 & $275.34^{* *}$ & 1 & $75.11^{* *}$ \\
\hline - Progenies $v s \mathrm{G}_{1}$ & 1 & $278.73^{* *}$ & 1 & $40.30^{* *}$ \\
\hline- Progenies $v s \mathrm{G}_{2}$ & 1 & $32.16^{* *}$ & 1 & $46.01^{* *}$ \\
\hline$-\mathrm{G}_{1} v s \mathrm{G}_{2}$ & 1 & $18.86^{* *}$ & 251 & 1.71 \\
\hline Residue & 356 & 1.88 & 343 & \\
\hline Total & 448 & & 21.0 & \\
\hline CV\% & 20.0 & & 6.20 & \\
\hline Overall average & 6.81 & & & \\
\hline
\end{tabular}

${ }^{1}$ Transformed data to $\sqrt{\mathrm{x}+0.5}$; ** and *significant values at 1 and $5 \%$ probability by the $\mathrm{F}$ test.

The individual and partial diallel analysis for the traits SEV and AUDPC, along with the effects of genotypes, broken down into GCA and SCA and the contrast between the means of the groups $\left(\mathrm{G}_{1} v s \mathrm{G}_{2}\right)$, revealed significant differences for most sources of variation, except for the contrast between the means of the groups $\left(\mathrm{G}_{1} v s \mathrm{G}_{2}\right)$ to the trait AUDPC, which was not significant (Table 3).

The significance of the effects of the GCA and SCA $(\mathrm{P} \leq 0.01)$ indicates the acting of additive and non-additive effects in the control of the traits SEV and AUDPC (Table 3), suggesting the existence of differences in the concentration of favorable alleles between the parents of the same group and genetic divergence between the groups of parents evaluated for resistance to pathogens M. phaseolina and T. cucumeris.

Table 3. Summary of the diallel analysis for severity of charcoal rot (SEV) and the area under the disease progress curve for the web blight (AUDPC) relating to the evaluation of cowpea genotypes from group 1, group 2 and its $\mathrm{F}_{2}$ populations.

\begin{tabular}{|c|c|c|c|c|}
\hline \multirow[t]{2}{*}{ SV } & \multicolumn{2}{|c|}{ SEV } & \multicolumn{2}{|c|}{ AUDPC } \\
\hline & $\mathrm{DF}$ & MS & $\mathrm{DF}$ & MS \\
\hline Treatments & 88 & $14.11^{* *}$ & 88 & $13.66^{* *}$ \\
\hline $\mathrm{GCA}_{1}$ & 13 & $22.45^{* *}$ & 13 & $23.28^{* *}$ \\
\hline $\mathrm{GCA}_{2}$ & 4 & $6.58^{* *}$ & 4 & $14.29 * *$ \\
\hline SCA & 70 & $11.45^{*}$ & 70 & $12.00^{* *}$ \\
\hline $\mathrm{GCA}_{\mathrm{G} 1} v s \mathrm{GCA}_{\mathrm{G} 2}$ & 1 & $122.74 * *$ & 1 & $1.58^{\mathrm{ns}}$ \\
\hline Residue & 356 & 1.88 & 251 & 1.71 \\
\hline $\mathrm{GCA}^{(1) / S C A}$ & 1.59 & & 1.74 & \\
\hline$\phi \mathrm{g} / \phi_{\mathrm{s}}\left(\mathrm{G}_{1}\right)$ & 0.13 & & 0.13 & \\
\hline$\phi_{\mathrm{g}} / \phi_{\mathrm{s}}\left(\mathrm{G}_{2}\right)$ & 0.07 & & 0.17 & \\
\hline
\end{tabular}

$\mathrm{ns}, * *, *$ Non-significant and significant effects at 1 and $5 \%$ probability by the $\mathrm{F}$ test, respectively; ${ }^{(1)} \mathrm{GCA}$ value obtained from the weighted average of $\mathrm{GCA}_{1}$ and $\mathrm{GCA}_{2} ; \phi \mathrm{g}$ : component associated with the GCA; $\phi \mathrm{s}$ : component associated with the SCA; $\phi \mathrm{g} / \phi \mathrm{s}$ : ratio of the components relating to the additive and dominant effects, respectively.

Genetics and Molecular Research 16 (3): gmr16039804 
Estimates of the effect of GCA in group 1, for the trait SEV (Table 4) ranged from -0.86 (BRS Guariba) to 1.88 (IT98K-491-4), while in group 2, ranged from -0.24 (MNC02675F-4-10) to 0.44 (MNC02-675F-4-9). For such characteristics the traits BR 14-Mulato, BRS Marataoã, BRS Tumucumaque and BRS Guariba stood out for presenting less significant values of GCA, being the most recommended to be used as parents in breeding for resistance to M. phaseolina in cowpea. However, the other parents who have submitted estimates of negative and non-significant GCA (Table 4) may also be referred to as sources of resistance and with potential to reduce the severity of charcoal rot.

Table 4. Estimates of the effect of GCA between the parents of cowpea in group 1 (ĝi) and group 2 (ĝj) for severity of charcoal rot (SEV) and the area under the disease progress curve for web blight (AUDPC).

\begin{tabular}{l|c|c}
\hline \multirow{2}{*}{ Group 1 } & SEV & AUDPC \\
\cline { 2 - 3 } & gi & $-0.79^{* *}$ \\
\hline BR 14-Mulato & $-0.57^{* *}$ & $0.75^{* *}$ \\
\hline Canapuzinho & 0.31 & $-0.55^{* *}$ \\
\hline IT98K-491-4 & $1.88^{* *}$ & $-1.24^{* *}$ \\
\hline IT98K-506-1 & $0.46^{*}$ & -0.31 \\
\hline MNC01-649F-2-1 & 0.32 & $0.60^{* *}$ \\
\hline MNC02-677F-5 & -0.16 & $0.72^{* *}$ \\
\hline MNC02-689F-2-8 & -0.11 & $0.78^{* *}$ \\
\hline BRS Aracê & 0.37 & $1.10^{* *}$ \\
\hline BRS Marataoã & $-0.64^{* *}$ & $0.76^{* *}$ \\
\hline MNC03-737F-5-9 & -0.38 & $-0.45^{* *}$ \\
\hline BRS Tumucumaque & $-0.69^{* *}$ & $0.33^{* *}$ \\
\hline BRS Cauamé & $0.43^{*}$ & $-1.21^{* *}$ \\
\hline BRS Itaim & -0.35 & $-0.48^{* *}$ \\
\hline BRS Guariba & $-0.86^{* *}$ & $\hat{\mathrm{g} j}$ \\
\hline Group 2 & $\hat{\mathrm{g} j}$ & $-0.59^{* *}$ \\
\hline IT98K-1092-1 & -0.19 & $0.50^{* *}$ \\
\hline MNC03-761F-1 & -0.07 & $0.38^{* *}$ \\
\hline MNC02-675F-4-9 & $0.44^{* *}$ & $-0.22^{*}$ \\
\hline MNC02-675F-4-10 & -0.24 & -0.07 \\
\hline MNC02-675F-9-2 & 0.06 & \\
\hline
\end{tabular}

** and * Significant values at 1 and $5 \%$ probability by the $t$-test.

From the observation of the effects estimates of GCA (Table 4), it is observed that the majority of parents showed negative and significant effects for the parameter AUDPC, highlighting the genitors BR 14-Mulato (-0.79), IT98K-491-4 (-0.55), IT98K-506-1 (-1.24), BRS Tumucumaque (-0.45), BRS Itaim (-1.21), BRS Guariba (-0.48), IT98K-1092-1 (-0.59), and MNC02-675F-4-10 (-0.22) for presenting values of gi (GCA) negative and significant, being indicated as promising sources for use in breeding programs aiming at producing progenies resistant to T. cucumeris.

According to the estimates of SCA (Table 5), among the thirty two crossings of cowpea that stood out with regard to the resistance to M. phaseolina, seven of them had four parents with high absolute values and effects of GCA to the trait SEV (BR 14-Mulato, BRS Marataoã, BRS Tumucumaque, and BRS Guariba) in combination with parents who have also demonstrated good absolute and negative values of GCA (IT98K-1092-1, MNC03-761F-1 and MNC02-675F-4-10), although not significant by the $t$-test (Table 4).

The estimates of SCA for resistance of cowpea progenies to M. phaseolina and T. cucumeris (Table 5), the majority of the combinations with effects of SCA and with negative values for both traits stood out. 
Analyzing the severity of angular leaf spot (Pseudocercospora griseola) in black beans by means of the diallel method, Moura (2013) also noted the significance of all sources of variation, highlighting the predominance of additive effects in the control of resistance to the pathogen. This allows us to infer that there is a difference in favorable allele concentration among the parents of the same group and genetic divergence between the groups of parents.

According to Carvalho (2010), the association of the existence of variability of the SCA with the high magnitude of quadratic component of the SCA evidences the presence of genetic divergence associated to high complementarity of the studied genotypes.

However, this study, the ratio between the quadratic components associated to effects of the general $\left(\phi_{\mathrm{g}}\right)$ and specific $\left(\phi_{\mathrm{s}}\right)$ combination of $\mathrm{G}_{2}$ in relation to the $\mathrm{G}_{1}$ to SEV (Table 3 ), presented in a low magnitude, being expected, once occurred prior selection for the trait in question. While, the AUDPC showed high magnitude of the quadratic component related to SCA $\left(\phi_{s}\right)$, as well as the low value of reason $\phi_{g} / \phi_{s}$ (Table 3 ) confirming previous selection of cowpea genotypes evaluated, indicating the complementarity of parents studied for the trait into consideration, as the approached by Carvalho (2010).

The significance of the effects of the GCA and SCA $(\mathrm{P} \leq 0.01)$ recorded infer about the acting of additive and non-additive effects in the control of the traits SEV and AUDPC (Table 4), suggesting the existence of differences in the concentration of favorable alleles, genetic diversity and the presence of complementation between the cowpea genotypes evaluated for resistance to pathogens. According to Krause et al. (2012), estimates of GCA provide information on the concentration of favorable alleles for the improvement of the trait in study, since the magnitude of the GCA is directly proportional to the frequency of alleles. In this way, they inferred that populations derived from crosses between parents who have high absolute values of GCA have a higher frequency of favorable alleles, increasing the likelihood of finding lines, which surpass the parents. Therefore, during the choice of populations, we should seek for crosses that have a high average and at least one of the parents have high absolute value of GCA (Cruz et al., 2012).

The crosses of cowpea that presented values of negative and significant SCA (Table 5), which contain at least one of the parents with values of negative and significant GCA (Table 4), should be considered as promising in the development of genotypes for resistance to M. phaseolina and T. cucumeris.

Thus, the employment of hybridization in breeding programs, allowing the recombination, is of extreme interest in generating greater genetic variability in plants, allowing the use of selective processes that effectively result in significant genetic gains, through the expression of the potential of segregating populations for selection (Bernardo, 2002).

Studies of reaction of cowpea genotypes for resistance to pathogens $M$. phaseolina performed by Athayde Sobrinho (2004), Noronha et al. (2009, 2010), Lima et al. (2012a,b) and for T. cucumeris developed by Nechet et al. (2006) and Nechet and Halfeld-Vieira (2007), emphasizes the necessity of recombination of resistant materials and potential promising sources for study and obtaining progenies with good level of resistance to these pathogens.

\section{CONCLUSIONS}

The additive effects predominate in the genetic control of the traits SEV and AUDPC for web blight, allowing gain with the selection of promising genotypes, and consequently, the achievement of strains resistant to both diseases.

Genetics and Molecular Research 16 (3): gmr16039804 
The genitors BR 14-Mulato, BRS Tumucumaque and BRS Guariba have a higher concentration of favorable alleles for resistance to both pathogens $M$. phaseolina and $T$. cucumeris in cowpea.

The combinations BR 14-Mulato $\mathrm{x}$ MNC02-675F-4-10, BRS Tumucumaque $\mathrm{x}$ IT98K-1092-1, BRS Tumucumaque x MNC02-675F-4-10, BRS Tumucumaque x MNC02675F-9-2, BRS Guariba x IT98K-1092-1, BRS Guariba x MNC02-675F-4-9, and BRS Guariba x MNC02-675F-4-10 showed high potential to obtain resistant cultivars to M. phaseolina and T. cucumeris in cowpea, simultaneously.

\section{Conflicts of interest}

The authors declare no conflict of interest.

\section{ACKNOWLEDGMENTS}

Research supported by Coordenação de Aperfeiçoamento de Pessoal de Nível Superior (CAPES) and Fundação de Amparo à Pesquisa do Estado do Piauí (FAPEPI), and we thank Embrapa Meio-Norte and Embrapa Roraima for the accorded infrastructure, availability of the space and staff assistance for the experiments.

\section{REFERENCES}

Abawi GS and Pastor-Corrales MA (1990). Root rots of beans in Latin America and Africa: diagnosis, research methodologies and management strategies. CIAT, Cali.

Athayde Sobrinho C (2004). Patossistema caupi x Macrophomina phaseolina: método de detecção em sementes, esporulação e controle do patógeno. Doctoral thesis, Escola Superior de Agricultura "Luiz de Queiroz", USP, Piracicaba.

Athayde Sobrinho C, Viana FMP and Santos AA (2005). Doenças fúngicas e bacterianas. In: Feijão-caupi: avanços tecnológicos (Freire Filho FR, Lima JA de A and Ribeiro VQ, eds.). Embrapa Informação Tecnológica, Brasília, 461-484.

Bernardo R (2002). Breeding for Quantitative Traits in Plants. Stemma Press, Woodbury.

Campbell CL and Madden LV (1990). Introduction to plant disease epidemiology. Wiley, New York.

Carvalho LCB (2010). Cruzamentos dialélicos visando à obtenção de populações produtivas e biofortificadas para os teores de ferro, zinco e proteína em feijão-caupi. Master's thesis, Universidade Federal do Piauí, Teresina.

Cruz CD (2006). Programa Genes: Biometria. Editora UFV, Viçosa.

Cruz CD, Regazzi AJ and Carneiro PCS (2012). Modelos biométricos aplicados ao melhoramento genético. 4th edn. vol 1. Editora UFV, Viçosa.

Ferreira DF (2011). Sisvar: a computer statistical analysis system. Cienc. Agrotec. 35: 1039-1042. https://doi.org/10.1590/ $\underline{\text { S1413-70542011000600001 }}$

Freire Filho FR, Ribeiro VQ, Barreto PD and Santos AA (2005). Melhoramento Genético. In: Feijão-caupi: avanços tecnológicos (Freire Filho FR, Lima JAA and Ribeiro VQ, eds.). Embrapa Informação Tecnológica, Brasília, 29-75.

Freire Filho FR, Rocha MM, Damasceno-Silva KJ, Ribeiro VQ, et al. (2013). Feijão-caupi no Brasil: produção, melhoramento genético e perspectivas. In: Melhoramento Genético de Plantas no Nordeste (Vidal Neto FC and Cavalcanti JJV, eds.). Embrapa, Brasília, 85-149.

Freire Filho FR, Ribeiro VQ, Rocha MM, Silva KJD, et al. (2011). Feijão-caupi: produção, melhoramento genético, avanços e desafios. Brasília: Embrapa Informação Tecnológica.

Freire Filho FR, Vilarinho AA, Cravo MS and Cavalcante ES (2007). Panorama da cultura do feijão-caupi no Brasil. In: Workshop sobre a Cultura do Feijão-caupi (Zilli JE, Vilarinho AA, Araújo WF and Melo VF, eds.). Embrapa Roraima, Boa Vista, 7-12.

Geraldi IO and Miranda Filho JB (1988). Adapted models for the analysis of combining ability of varieties in partial diallel crosses. Rev. Bras. Genet. 11: 419-430.

Genetics and Molecular Research 16 (3): gmr16039804 
Griffing B (1956). Concept of general and specific combining ability in relation to diallel crossing systems. Aust. J. Biol. Sci. 9: 463-493. https://doi.org/10.1071/BI9560463

Krause W, Rodrigues R and Leal NR (2012). Capacidade combinatória para características agronômicas em feijão de vagem. Rev. Ciênc. Agron. 43: 522-531.

Lima LRL, Sousa CMB, Pires CJ, Sousa MB, et al. (2012a). Avaliação de germoplasma de feijão-caupi de porte ereto e semiereto para resistência à Macrophomina phaseolina (Tassi) Goid. In: Anais do II Congresso Brasileiro de Recursos Genéticos, Recife.

Lima LRL, Sousa CMB, Torres MHRM, Noronha MA, et al. (2012b). Reação de germoplasma de feijão-caupi de porte prostrado à Macrophomina phaseolina (Tassi) Goid. In: Anais do II Congresso Brasileiro de Recursos Genéticos, Recife.

McKinney HH (1923). Influence of soil temperature and moisture on infection of wheat seedlings by Helminthosporium sativum. J. Agric. Res. 26: 195-218.

Moura LM (2013). Cruzamentos dialélicos visando à escolha de genitores no melhoramento de feijão preto. Master's thesis, Universidade Federal de Viçosa, Viçosa.

Nechet KL and Halfeld-Vieira BA (2007). Reação de cultivares de feijão-caupi a mela (Rhizoctonia solani) em Roraima. Fitopatol. Bras. 32: 424-428. https://doi.org/10.1590/S0100-41582007000500009

Nechet KL, Halfeld-Vieira BA and Souza GR (2009). Estudos Epidemiológicos e de controle da mela (Rhizoctonia solani) do feijão-caupi. Documentos $\cdots: 12$.

Nechet KL, Vilarinho AA and Halfeld-Vieira BA (2006). Reação de genótipos de feijão-caupi a mela (Rhizoctonia solani) em três ecossistemas de Roraima. In: Anais do Congresso Nacional de Feijão-Caupi, Teresina.

Nkalubo ST, Melis R, Derera J, Laing MD, et al. (2009). Genetic analysis of anthracnose resistance in common bean breeding source germplasm. Euphytica 167: 303-312. https://doi.org/10.1007/s10681-008-9873-4

Noronha MA, Athayde-Sobrinho C, Girão Filho JE, Gonçalves SR, et al. (2009). Reação de genótipos de feijão-caupi a Macrophomina phaseolina. Trop. Plant Pathol. 34: 248.

Noronha MA, Gonçalves SR, Silva HK and Silva KJD (2010). Influência da concentração de inóculo de Macrophomina phaseolina na severidade da doença em genótipos de feijão-caupi. Trop. Plant Pathol. 35: 147.

Orawu M, Melis R, Laing M and Derera J (2013). Genetic inheritance of resistance to cowpea aphid-borne mosaic virus in cowpea. Euphytica 189: 191-201. https://doi.org/10.1007/s10681-012-0756-3

Rêgo MSC, Lopes ACA, Rocha MM, Freire Filho FR, et al. (2006). Avaliação de métodos de cruzamentos artificiais em feijão-caupi [Vigna unguiculata (L.) WALP.]. In: Anais do Congresso Nacional de Feijão-Caupi, Teresina. Available at [http://www.cpamn.embrapa.br/anaisconac2006/resumos.htm].

Songa W, Hillocks RJ, Mwango'mbe AW, Buruchara R, et al. (1997). Screening common bean accessions for resistance to charcoal rot (Macrophomina phaseolina) in eastern Kenya. Exp. Agric. 33: 459-468. https://doi.org/10.1017/ $\underline{\mathrm{S} 001447979700402 X}$

Timko MP and Singh BB (2008). Cowpea, a multifunctional legume. In: Genomics of Tropical Crop Plants (Moore PH and Ming R, eds.). Springer, New York, 227-258.

Van Schoonhoven A and Pastor-Corrales MA (1987). Sistema estándar para la evaluación de germoplasma de frijol. CIAT, Cali.

Genetics and Molecular Research 16 (3): gmr16039804 